\title{
THE MODERATION EFFECT OF INFORMATION SYSTEMS ON VOCATIONAL HIGH SCHOOL PRINCIPAL DECISION-MAKING MODEL
}

\author{
Didi Supriadi ${ }^{1,2 *}$, Husaini Usman ${ }^{1}$, Cepi Safruddin Abd Jabar ${ }^{1}$ \\ ${ }^{1}$ Universitas Negeri Yogyakarta, Indonesia \\ ${ }^{2}$ Universitas Sarjanawiyata Tamansiswa, Indonesia \\ *e-mail: didi.supriadi@ustjogja.ac.id
}

\begin{abstract}
A decision-making process in an organization is more effective if it is supported by reliable and valid information systems. Management Information System (MIS) and Decision Support System (DSS) are two systems commonly used by organizational leaders to collect information for making the Quality of Decision (QD). This study aimed to empirically investigate MIS influences on vocational high school principals' QD. Besides, this study examined the moderation effect of the DSS on the decision-making processes. This quantitative research employed the survey method and purposive sampling technique. As many as 60 vocational high school principals and vice-principals in Yogyakarta, Indonesia were the participants of this study. They filled in questionnaires consisting of 19 items that were developed using the Likert scale. The quantitative data obtained were analyzed using Structural Equation Modeling. The research findings show that MIS has a significant effect on the quality of the decision-making process by vocational high school principals. However, for improving the decision quality, the model must be assisted by DSS as the moderator variable. MIS carries information required for principals while DSS provides data, model, and analysis instruments used for special cases in vocational high schools.
\end{abstract}

Keywords: management information system, decision support system, decision-making, vocational high school principals.

\section{EFEK MODERASI PADA MODEL PENGAMBILAN KEPUTUSAN KEPALA SEKOLAH SMK}

\begin{abstract}
Abstrak: Proses pengambilan keputusan dalam suatu organisasi lebih efektif jika didukung oleh sistem informasi yang valid dan dapat dipercaya. Sistem Informasi Manajemen (SIM) dan Sistem Pendukung Keputusan (SPK) adalah dua sistem yang umumnya digunakan oleh pemimpin organisasi untuk memperoleh informasi yang digunakan dalam pengambilan keputusan. Tujuan penelitian ini adalah untuk melihat pengaruh SIM terhadap kualitas pengambilan keputusan oleh kepala sekolah SMK di Indonesia secara empiris. Di samping itu, penelitian ini juga bertujuan untuk menunjukkan efek moderasi SPK pada pengambilan keputusan kepala sekolah SMK. Penelitian kuantitatif ini menggunakan metode survei dan teknik sampling purposive. Sebanyak 60 responden yang terdiri dari kepala sekolah dan wakil kepala sekolah SMK di Yogyakarta, Indonesia terlibat dalam penelitian ini. Mereka memberikan jawaban pada 19 pernyataan pada kuesioner berskala Likert. Data kuantitatif yang diperoleh selanjutnya dianalisis menggunakan Structural Equation Modeling. Hasil penelitian ini menunjukan bahwa SIM berpengaruh secara signifikan terhadap kualitas proses pengambilan keputusan yang dilakukan oleh kepala sekolah SMK. Walaupun demikian, untuk meningkatkan kualitas keputusan, model haruslah diperkuat oleh SPK sebagai variabel moderator. SIM memberi informasi yang diperlukan untuk kepala sekolah, sementara itu, SPK menyediakan data, model, dan instrumen analisis untuk mendukung kasus-kasus luar biasa di SMK.

Kata Kunci: sistem informasi manajemen, sistem pendukung keputusan, pengambilan keputusan, kepala sekolah Sekolah Menegah Kejuruan.
\end{abstract}

\section{INTRODUCTION}

The decision-making process is a series of logical thinking activity. Making decision in a school organization involves almost all managerial functions from the problem identification to the decision implementation processes (Yukl, 2003). It determines the organization performance in achieving its goal (Rochaety, Rahayuningsih, \& 
Yanti, 2007). This also implies that the decisionmaking remains critical activity in a management system (Robbins, 2003; Hoy \& Miskel, 2013). The decision-making process takes a substantial role as its process should boast on the organization motivation, leadership, communication, coordination, and transformation (Engkoswara \& Komariah, 2010).

Robbins (2003) lists five steps of rational decision-making as follows: a) identify the problem, b) identify the decision criteria, c) allocate the criteria weight, d) develop the solution alternative, e) evaluate the solution alternative, and $\mathrm{f}$ ) choose the best solution alternative. Basically, the decision-making is systematic approach on recognizing problem, collecting facts and data, deciding the alternative solution, and executing the precise planning (Skalski \& Romero, 2011). This means that the leader makes a decision in planning, implementing, supervising, and organizing (Abduh, 2015). The role of a managerial leader in decision-making process is very essential mainly employ skills and knowledge from their organizational experience (Anwar, 2014).

The industrial revolution 4.0 pushes organization to respond the change quickly as its real time. Hermann, Pentek, \& Otto (2016) state that in industrial era 4.0, school principals need technical supports such as a system which can merges and evaluate information in order to solve urgent problems quickly. This means that the school principals have to own technology literacy. Aryawan (2019) expounds that one of school principal leadership principles applied in industrial revolution 4.0 is oriented to the facility and infrastructure improvement on the communication and information technology. In education contexts, the school principals have to shift their leadership style from a sole decision maker to inviting others and support instrument in decision-making process (Slater, 2005).

The Management Information System (MIS) and Decision Support System (DSS) are operational supporting systems in an organization. Keshtegar \& Vakili (2018) stated that the MIS provides information needed in organization management, while the DSS carries data, model and analysis instruments for helping the organization leaders in adopting the unstructured cases.

The Management Information System
(MIS) is very significant for assisting the school principals in running decision-making process (Abduh, 2015). The system allows the school principal to identifying the problems easily, exposing the alternative solutions, choosing the best solution and carrying out the solution (Bryson, 2004). Information systems are often described as a technology intended to regulate staff actions and produce information to improve the ability of managers to oversee work results (Baglieri, Metallo, Rossignoli, \& Iacono, 2014). Information systems become agents of organizational change that are important for principals to manage the changes effects (Lake \& Drake, 2014).

Decision support system is an interactive software-based computerized information system intended to help decision makers compile useful information from raw data and documents to identify and solve problems and to make decisions (National Forum on Education Statistics, 2006). A decision support systems (DSS) is a computerbased interactive system, it used to help decisionmakers properly use data and models (Chiu \& Huang, 2016). The DSS as a part of knowledge management system is used to support the decision-making process in an organization. This interactive information system provides information, modeling, and data manipulation in semi-structured and unstructured situations (Silich, Savelev, \& Isaev, 2016).

The decision support system in educational settings has an imperative role in organizational and quality development. It is used by school principals to integrate the information in their planning and execution of mission. Several studies have reported the positive impact of data decision support by acknowledging its contribution in assessing how various factors influence teaching and learning at the schools (Thorn, 2002).

The school principal places the highest position that plays an important role in decision making (Triwiyanto, 2015). A school principle as a school management executor and decision maker formally owns a great responsibility in leading the school. According to the Government Regulation No. 19 / 2017, one of a school principal's duties is managerial that required due to the heterogeneous problems the school faced. The school principal leadership focus, of course, lays on the decision-making on whole schools problems and program (Nurhidayati, 2015). No 
matter how critical or insignificant the problem is, the school principal must find the way out since all decisions made determine the next school performance and orientation (Kadir, 2017). So, as a decision maker, the school principal should possess professional and capability in leadership for generating rational solutions.

Yet, a school principal has faced some troubles during their decision-making process. First, the decision-making process of the school principal has been influenced by unreliable factors. Psychological factors such as perception, roles, attitude, personality, motivation and job satisfaction (Astuti, 2018), for example, have affected on the decision-making process. The other factors are individual worth, personality and risk-taking tendency (Ayub, Wahyudi, \& Syukri, 2014), gender, experience, and competency (Kasprzhak \& Bysik, 2015). Those implausible factors can be ignored if the school principal has an access to the accurate data system.

Second, the school principal has found technical problems in the decision-making and planning processes. Third, there is a leadership line boundary. The school principal has not gained full autonomy in decision-making process. Structurally, the school principal has to follow the upper-line leaders' decisions. For instance, the school principal has slowly run the decisionmaking process on the school infrastructure management due to the complicated and lengthy bureaucracy and regulation (Ayub et al., 2014). Hence, the difficulties faced by the school principals above are generally because of the lack of data and up-to-date information availability on planning parameters.

Nowadays, not many school principals applied the data-driven in their decisionmaking and planning process, however, there is still hope that the use of data-driven is used massively among school principals (Bigner, 2017). There were two significant variables in determining the effectiveness of the school planning implementation, namely the managerial performance of the school principal, and the utilizing of the school management information system (Wiguna, 2017).

For gaining the decision-making effectiveness, the school principle should conform between the problem and solution. Lamentably, in the conformation process, some troubles may appear. Putra (2014) identifies five prominent obstacles in decision-making process; 1) the school principle rarely invites teachers in the decision-making process, 2) the school principle makes ineffective decision due to the lack of quality and teachers' acceptance considerations, 3 ) the school principle employs insufficient data and information, 4) the school principle is less adaptable to the new situation and conditions before making decisions, 5) the school principle is in hurry in making decisions and ignore the appropriate procedures. Thus, the school principal plays a center role in establishing the school planning implementation.

Another prominent variable noted in determining the school planning accomplishment is the school data and information system. The absence of the comprehensive data and information causes incompatible decision (Yanti, 2013). The lack of data and information comprise several conditions, such as; 1) the unavailable accurate and factual data for strategic planning formulation, 2) the inaccessible decisionmaking support system as a part of education management information system, 3) the absence of facility and infrastructure for establishing the management information system, 4) the lack of management information system use. If the school principal fails in formulating the school strategic planning which is not supported by the adequate management information system, the school principal might make wrong decisions (Wiyardi, 2016). Therefore, the management information system plays a fundamental role in decision-making process.

The accountability demands encourage the school principal to employ and analyze more delicate data. Yet, a vocational school principals who must organize 9 expertise areas, 49 expertise program, and 146 expertise competences (Permendikbud RI 2018 No. 06/D. $\mathrm{D} 5 / \mathrm{KK} / 2018$ ). In this case, it is mandatory that the vocational school principal must have access on the complete database which provides information for supporting the decision-making process. The data-driven decision-making process has been the school leadership practice focusing on the education policy and practices (Luo, 2008; James, Milenkiewicz, \& Bucknam, 2008). In other words, the vocational school principals should be capable in managing the data as well as matching to the government regulation.

However, the vocational school principals 
often miss in making appropriate decisions due to the less accurate data accessed. This leads to the unmeasured decisions made. In other words, the quality of the decision made is still questionable. Thus, the present research is to obtain the influence of Management Information System on the quality of decision making of the vocational school principals. Another goal is to obtain the moderation effect of the decision-support system on the vocational school principals' decision processes.

\section{METHODS}

The present quantitative research with survey method. It employs a questionnaire with a purposive sampling technique. The research was run in June - August 2019 by applying three research variables, namely the Management Information System (MIS), Decision Support System (DSS) and the Quality of Decision (QD). The correlation among those variables are presented on the Figure 1.

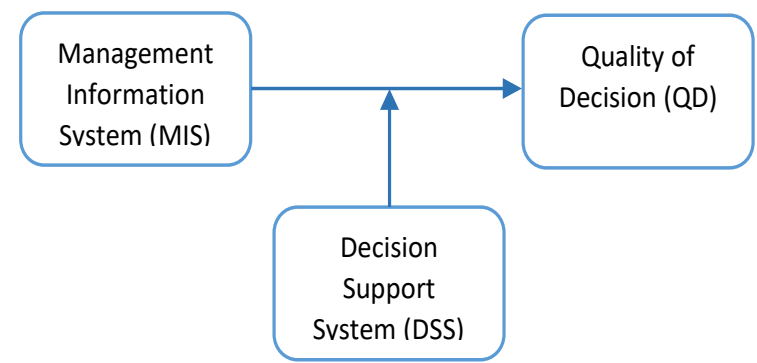

Figure 1. Conceptual Model modified from Keshtegar \& Vakili (2018)

The data collection tool used in the research is a questionnaire consisting of four sections. The first section contains the introductory information about respondents. The respondents involved in the current research are 60 vocational school principals and vice principals in Yogyakarta, Indonesia. The second section is Management Information System (MIS). The four items employed in the present study are derived from the questionnaire from Abu-Samaha \& Shishakly (2008); Keshtegar \& Vakili (2018). The third section of the questionnaire is depicted to the Decision Support System (DSS). The DSS variable is measured in five items modified from Fakeeh (2015); Keshtegar \& Vakili (2018). The last section named the Quality of Decision (QD). The ten instruments of QD is adopted from Lizarraga, Baquedanoa, Olivera, \& Closas (2009) and Doherr, Christalle, Kriston, Harter, \& Scholl (2017). The 19 questionnaire items above are responded in 5-Likert scale between (1) Strongly Disagree and (5) Strongly Agree.

Here is the description and validity test results of the three current research variables (see Table 1); the Management Information System (MIS), the Decision Support System (DSS), and the Quality of Decision (QD). The test of validity and reliability used 30 respondents of vocational school principals and vice principals. The validity test used Confirmatory Factor Analysis (CFA) with loading factor $>.50$. The reliability test used Average Variance Extract (AVE) and Composite Reliability (CR).

Table 1. Confirmatory Factor Analysis Result

\begin{tabular}{|c|c|c|c|}
\hline \multirow{2}{*}{ Item Number } & \multicolumn{3}{|c|}{ Factor Loadings } \\
\hline & MIS & DSS & QD \\
\hline MIS.1 & .847 & & \\
\hline MIS. 2 & .868 & & \\
\hline MIS.3 & .901 & & \\
\hline MIS.4 & .830 & & \\
\hline DSS. 1 & & .902 & \\
\hline DSS. 2 & & .839 & \\
\hline DSS. 3 & & .859 & \\
\hline DSS.4 & & .814 & \\
\hline DSS. 5 & & .626 & \\
\hline QD.1 & & & .774 \\
\hline QD.2 & & & .752 \\
\hline QD.3 & & & .764 \\
\hline QD.4 & & & .766 \\
\hline QD.5 & & & .688 \\
\hline QD.6 & & & .881 \\
\hline QD.7 & & & .821 \\
\hline QD.8 & & & .894 \\
\hline QD.9 & & & .859 \\
\hline QD.10 & & & .895 \\
\hline
\end{tabular}

The Table 1 also indicates that all variable items tested using the factor loadings were valid and feasible. This means that those research variable items fulfilled requirements to be used as the research instruments. The validity test is used to check whether the variable items designed enable to describe the valid variables of the research. A variable item passes a validity test if its factor loadings is above .50. From the Table 1, it can be seen that the factor loadings values of the three variables ranged from .626 to .902 . This identifies that the variable items are valid. 
Besides, the Average Variance Extract (AVE) and Composite Reliability (CR) were also applied to test the validity and the reliability of the current research variables. The minimum requirement values of the validity and reliability of the research variables are more than .50 and .70 respectively. The Table 2 displays the test result of the AVE and CR of the present research.

Tabel 2. Average Variance Extract (AVE) and Composite Reliability (CR)

\begin{tabular}{lccc}
\hline & MIS & DSS & QD \\
\hline AVE & .743 & .662 & .660 \\
CR & .920 & .906 & .951 \\
\hline
\end{tabular}

The Table 2 shows that the AVE values of the research variables were between .660 and .743 , while the CR values ranged from .906 to 920. This means that all three variable used, namely MIS, DSS, and QD are valid and reliable to be used on the next research stages.

The researcher operated the Structural Equation Modeling (SEM) using WarpPLS software for analyzing the data. The type of software was chosen since it enables to analyze variant-based SEM model well-known as Partial Least Square. Additionally, the recent research data analysis allows the researcher to identify as well as to estimate the correlation among latent variables whether it was either linear or non-linear. Besides, the chosen software also has ability in measuring the moderation effects in SEM accurately (Sholihin \& Ratmono, 2014).

\section{FINDINGS AND DISCUSSIONS Findings}

The current research set 19 items which were divided into three groups namely MIS, DSS, and QD. The MIS was covered four items; 1) the information quality, 2) the flexibility of the MIS used, 3) the punctuality, and 4) the accessibility. The five items focused on the DSS functions in; 1) providing understandable information, 2) playing its roles, 3) serving integrated and consistent data, 4) improving the school principal's skills in decision-making process, and 5) increasing the effectiveness of the school principal's task. Last, the QD was compiled 10 items namely; 1) systematically and structurally process, 2) clear role and responsibility, 3) relevant decision criteria, 4) bias influence evaluation, 5) optional exploration, 6) uncertainty consideration, 7) reevaluation, 8) impact analysis, 9) transparency and documentation, and 10) effective communication. From the 60 respondents called for the current research, the responses result on the 19 questionnaire items is showed in Table 3.

Table 3. Statistic Description of Research Variables

\begin{tabular}{|c|c|c|c|}
\hline $\begin{array}{l}\text { Item } \\
\text { Number }\end{array}$ & Item & Mean & $S D$ \\
\hline MIS.1 & $\begin{array}{l}\text { The information quality of } \\
\text { MIS }\end{array}$ & 3.700 & .849 \\
\hline MIS.2 & $\begin{array}{l}\text { The flexibility in using the } \\
\text { MIS }\end{array}$ & 3.767 & 1.047 \\
\hline MIS.3 & $\begin{array}{l}\text { The punctuality of the } \\
\text { information processing }\end{array}$ & 3.650 & 1.022 \\
\hline MIS.4 & $\begin{array}{l}\text { The accessibility ease of } \\
\text { the MIS features }\end{array}$ & 4.000 & .864 \\
\hline DSS.1 & $\begin{array}{l}\text { The DSS information is } \\
\text { easy to understand. }\end{array}$ & 3.767 & .722 \\
\hline DSS.2 & $\begin{array}{l}\text { The DSS performs as it } \\
\text { should be }\end{array}$ & 3.783 & .783 \\
\hline DSS.3 & $\begin{array}{l}\text { All DSS data are fully } \\
\text { integrated and consistent. }\end{array}$ & 3.867 & .724 \\
\hline DSS.4 & $\begin{array}{l}\text { The DSS improves the } \\
\text { ability in good decision } \\
\text { making. }\end{array}$ & 3.967 & .688 \\
\hline DSS.5 & $\begin{array}{l}\text { The DSS increases the task } \\
\text { effectiveness. }\end{array}$ & 3.617 & .904 \\
\hline QD.1 & $\begin{array}{l}\text { The decision making } \\
\text { process is done } \\
\text { systematically and } \\
\text { structurally. }\end{array}$ & 3.617 & .585 \\
\hline QD.2 & $\begin{array}{l}\text { The decision maker has } \\
\text { clear role and responsibility }\end{array}$ & 3.583 & .591 \\
\hline QD.3 & $\begin{array}{l}\text { The decision criteria are } \\
\text { relevant to the goal and } \\
\text { decision contexts. }\end{array}$ & 3.783 & .454 \\
\hline QD.4 & $\begin{array}{l}\text { Evaluating the internal and } \\
\text { external bias influences }\end{array}$ & 3.683 & .504 \\
\hline QD.5 & $\begin{array}{l}\text { Actively exploring the } \\
\text { possible options }\end{array}$ & 3.400 & .718 \\
\hline QD.6 & $\begin{array}{l}\text { Concerning the uncertainty } \\
\text { factors }\end{array}$ & 3.517 & .725 \\
\hline QD.7 & $\begin{array}{l}\text { Re-evaluating when } \\
\text { the new information is } \\
\text { available }\end{array}$ & 3.367 & .688 \\
\hline QD.8 & $\begin{array}{l}\text { Conducting a decision } \\
\text { impact analysis }\end{array}$ & 3.500 & .770 \\
\hline QD.9 & $\begin{array}{l}\text { Ensuring the transparency } \\
\text { and documentation of the } \\
\text { decision notes }\end{array}$ & 3.367 & .688 \\
\hline QD.10 & $\begin{array}{l}\text { Effectively communicating } \\
\text { the decision basis }\end{array}$ & 3.500 & .748 \\
\hline
\end{tabular}


Generally, the Table 3 shows that the respondents assessed pretty good toward the given variable items. The Mean values among the three variables were between 3.367 and 4.000. The MIS which were comprised 4 items had Mean values from 3.650 to 4.000 . The DSS with its 5 items supported the Mean values between 3.617 and 3.967. While the QD containing 10 items had the Mean values ranged from 3.367 to 3.783 .

The Goodness-Of-Fit test is to find out whether the research model fits the criteria set. By applying WarpPLS, seven criteria used in Goodness-of-Fit test on the current research are presented in Table 4.

Tabel 4. Goodness-of-Fit Result

\begin{tabular}{lr}
\hline Model Fit and Quality Indices & \\
\hline Average Path Coefficient (APC) & .291 \\
Average $R$-Squared (ARS) & .219 \\
Average Adjusted R-Squared (AARS) & .191 \\
Average block VIF (AVIF) & 1.086 \\
Average Full Collinearity VIF (AFVIF) & 1.268 \\
Tenenhaus GoF (GoF) & .371 \\
$R$-Squared Coefficients QD & .219 \\
\hline
\end{tabular}

The model was assessed as ideal model as the AVIF and AFVIF criteria values were less than 3.3. Based on the Tenenhaus GoF, the research gained high assessors which was showed by its value at .371 . From the $R$-Square, the QD value was .219, indicating that MIS moderated by DSS elaborated the QD in $21.9 \%$ while the rest, i.e. $78.1 \%$ was detailed by other research variables and model. As some criteria values have fulfilled the Goodness-of-Fit test requirements, overall, the research model fits the criteria set on the Goodness-of-Fit test.

The first hypothesis was tested to examine whether the MIS as an independent variable was related to the QD of the vocational school principal. The result revealed that the model fitted to the given data $(R$-Square $=.219$ shown in Table 4). As presented in Table 5, the MIS had a significant positive impact on the QD of the vocational school principal $(b=.265$; $p$-value $=.014)$. This signifies that the better MIS results on the higher QD and in vice versa. In other words, the MIS affects on the QD of the vocational school principals.
Tabel 5. Path Coefficients and $p$-Values

\begin{tabular}{lcc}
\hline Path & Coefficients & $\boldsymbol{p}$-Value \\
\hline MIS $=>$ QD & .265 & .014 \\
MIS*DSS $=>$ QD & .318 & .004 \\
\hline
\end{tabular}

The second hypothesis was tested to investigate the moderation effect of DSS on the decision-making model of the school vocational principal. As seen in Table 5, the DSS had a significant positive impact as a moderator variable $(b=.318 ; p$-value $=.004)$. This signals that the DSS demonstrated a moderation effect which enabled in increasing the correlation between the MIS and QD of the vocational school principals.

\section{Structural Equation Modeling Analysis}

The Structural Equation Modeling (SEM) has been used broadly in many research for modeling a correlation between latent and manifest variables. The recent research presents a SEM approach by involving moderation effect on the decision-making process of the vocational school principal. Here is the model designed.

The structural modeling is commonly applied to identify the hypothesized correlation among the research variables i.e. exogenous or endogenous interrelated to the conceptual model. Figure 2 indicates that the MIS influenced QD in .265 while the DSS as a moderator variable between MIS and QD showed the value in .318.

\section{Discussions}

In the Management Information System (MIS), data, information and decision-making process are correlated each other. The data is transformed into needed information as a basic principle in decision-making process (Pornpandejwittaya, 2012). The accurate information gained from the valid and reliable data allows the organization leader to make accurate decision as well. This means that information plays a crucial role in decisionmaking process.

The recent research has proven that the MIS has affected on the quality of decision of the vocational school principals. The existence of a DSS will make the quality of the principal's decisions robust. The novelty of the research is finding the valid model that explain quality of decision can improve by management 


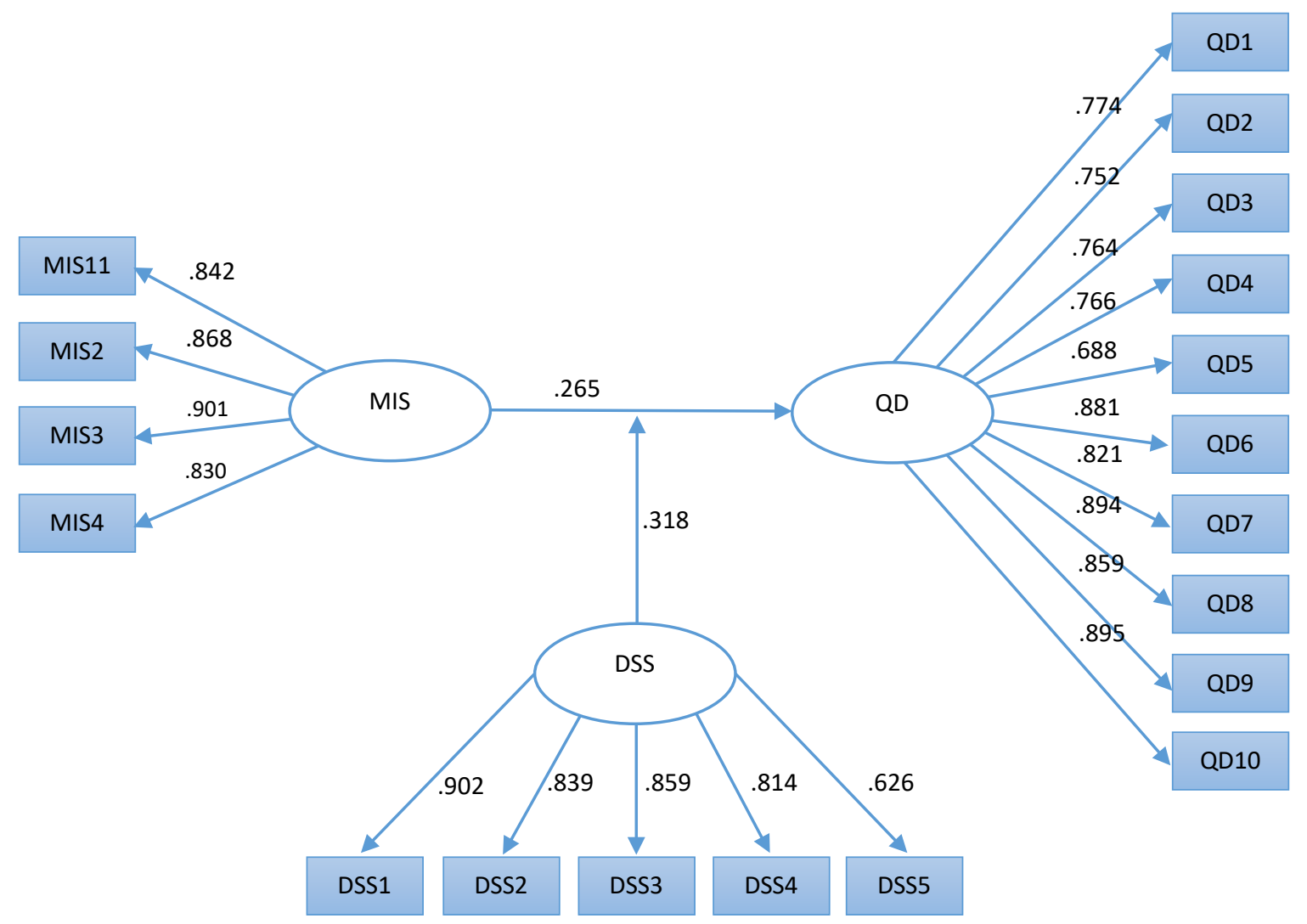

Figure 2. The Result Analysis of the Structural Equation Modeling with the Moderation Effect

information system and moderated by decision support system.

The most interesting thing found was that the accessibility aspect which supported the highest Mean value, i.e. 4.00 showed in Table 3. This means that the respondents mostly did not find any difficulties in accessing the MIS including its system features. The vocational school principals need several information such as input, resources, management, operation and education system product, which are very important as the consideration in the school problem identification. Those information is easily accessed through the MIS.

The easy access on the information needed has resulted on the effectiveness of the decision-making process. The vocational school principals are able to gain quick, reliable and valid information for supporting their decisions. The effective MIS results on the effective decision-making process. Due to its prominent role, the MIS is highly required in managing the school effectively (Gehlawat, 2014). Besides the effectiveness consideration, accountability demands have forced the school principal to put MIS as the primary reviews in making decisions.
The MIS enables the school principal access and analyze the provided information quickly for getting the accountable decision. The MIS, in this case, has promoted a prominent reference for the vocational school principals in recognizing the school problems which became the initial step in making decisions effectively.

Due to the various both internal and external problems faced, the school principals should have up-to-date information and sufficient managerial skills in decision-making process. Montana \& Charnov (2008) agrees that the MIS should integrate various aspects such as organization parties, procedure, data and instrument into a comprehensive system for generating a coherent information required in all organization levels. Tatnall (2011) clearly list three components involved in the existence of the MIS, namely, organization, technology, and human resources. It can be inferred that information compiled on the MIS should be comprehensible gained from accountable sources and transmitted from the trusted system.

As an educational organization, a school externally and formally has to stick to the national education policy and system. The MIS lets the 
vocational school principals access various information from the government and in vice versa. In developing a curriculum, for example, the schools must follow the national curriculum set by the Ministry of Education. In this case, the government provides the detail guidelines via the MIS provided on internet. The curriculum development results on several aspects adhered in the schools such as the students' information, reporting, coursework, students' assessment. Those information are very prominent data for the government in improving the national education quality standard.

The use of the MIS, in fact, is not only in Indonesia. Luena (2012) reported that Education Management Information System in Tanzania required the government involvement since the school needed qualified data and information for supporting the school policy-making, planning and managing the school resources. In other words, both schools and government as the organization have to connect each other for providing and gaining educational information policy and system. Besides, government also eases to monitor the school management through the MIS (Tatnall, 2011). In monitoring the school operational costs, for instance, the vocational school principals should document and report all the school expenses on the MIS. The report, then, can be accessed easily by the government.

Internally, the schools as education organization also take benefit from the MIS, such as the school promotion. Telem \& Pinto (2006) state that the MIS allows the school principasl recognize and aware of the MIS potential for school promotion means. Aldarbesti \& Saxena (2014) also assert that the MIS has supported the school management potentially. By showing the students achievement records to parents, for example, the school indirectly runs a marketing strategy. The parents who notice the school surpluses become the perfect and inexpensive marketing agents. For this goal, for sure, the role of the vocational school principals in making decisions is required. The school principals have to collect the excellent students' data, analyze their educational background, and sort the students' achievements which are in line with the school superiority.

Furthermore, the MIS can be a change agent for school management improvement (Benwari \& Dambo, 2013; Lake \& Drake,
2014). The changes can be occurred in various school units such as in admission process, reporting, library, financial, and many more. By recognizing the increasing number of dropout students, for example, the vocational school principals have to recall the data on the students' financial background, living area and academic reports. By analyzing the students' background, the vocational school principals may find out the problems which should be resolved. Therefore, the both external and internal problems faced by the vocational school principals spell out that the existing of the MIS becomes a compulsory at schools.

The MIS is very substantial for the vocational school principals in gaining comprehensive information used in problem identification before making decisions. This is understandable as the information system is designed to serve selected information used by the organization management in decisionmaking process of the organization planning, supervision and evaluation (Lestari, 2011). Each problem requires a certain procedure to pass through. However, if the school principals take wrong decisions due to the inappropriate information, it can be estimated that the problem is not solved or even it causes another problem. Aldarbesti \& Saxena (2014) articulate that the failure in employing the data effectively caused the intervention of education goal achievement. Thus, valid information on the MIS becomes the significant aspect in supporting the decisionmaking process of the vocational school principals. Somehow, the existence of the MIS insists the school principal to master technology.

The accessibility variable item of the current research also supported the idea of technology literacy. The vocational school principals responded positively related to the accessibility item. The vocational school principals mostly were capable in operating the MIS, picking information needed, and analyzing the information easily. They were also very familiar with the MIS features shown on the computer. In this case, those vocational school principals comprehended how to use internet for accessing the MIS-internet based. This was used for more external communication with organization outside the schools. For getting the government financial support, for instance, the vocational school principals should access 
the MIS which is connected to the Ministry of Education's website.

Ghaffarzadeh (2015) believe that communication and information technology allows the organization leaders run their organization globally as well as make decisions effectively. Besides the internet, the vocational school principals also enable to operate the intranet in their schools. The intranet connection is important in supporting the MIS which provides the schools information such as the number of books collected in the school library, the number of enrolled students, the schools activities, and many more. By knowing the number of collected books in the library, for example, the vocational school principals enable to identify and analyze the problem. Whether the quantity of the books equals to the total number of students can be one of the problems faced.

Furthermore, Omotayo \& Chigbundu (2017) state that the use of communication and information technology in the school increases and modernizes the administration and management roles. Thus, it is obligatory for the vocational school principals to master both internet and intranet due to the successful MIS access.

The current research also found that the DSS has moderated significantly between the MIS and QD of the vocational school principals in Yogyakarta, Indonesia. The MIS serves effective and accurate information for supporting the vocational school principals' decision-making process. From the Table 3, it can be seen that among the 5 variable items on the DSS, item 4 showed the highest Mean value; 3.967. The item refers to the role of the DSS in enhancing the vocational school principals' skills in making right decisions. According to Syafrizal (2010), DSS is a system used for supporting the management in the semi-structure decision-making process. The main role of the DSS is a support system for the organization leader in expanding their skills and knowledge. However, this system cannot be used to alter the management assessment. Principally, the DSS is designed to support the vocational school principal decision-making process by providing the computer-assisted system. The DSS allows the school principal to analyze and estimate the possible effects of the decision made. Moreover, this system is also used to help the school principal in setting the long-term decision (Singh, Bhardwaj, \& Sharma, 2013). The quality of decision making as an indicator of the effective implementation of instructional leadership for school principals (Usman, 2015).

Overall, the recent research reports that the MIS and DSS have been used for supporting the decision-making process in semi-structure decision situation without replacing the school principal evaluation and assessment on their decisions. The MIS carries information required for managing the organization, meanwhile, the DSS provides data, model, and analysis instruments for supporting extra ordinary cases in the organization (Keshtegar \& Vakili, 2018).

The impact of the quality of the principal's decision can be seen by teachers and staff responses to their leadership at school. There is a relationship between the principal's leadership style and the principal's decision-making style in the context of Indonesian schools. The findings of Hariri, Monypenny, \& Prideaux (2014) show that teachers perceive that principals must demonstrate rational decision-making styles and avoid avoidance decision-making styles.

\section{CONCLUSION}

The existence of MIS and DSS correlate positively to the QD in the vocational school principals' decision-making process. The MIS provides complete, reliable and valid information which is essential for supporting the vocational school principals in indicating and analyzing the school problems. Through the MIS, the vocational school principals are able to access both internal and external information. The easy access to the information needed results on improving the problem analysis skills of the vocational school principals.

Meanwhile, by applying the DSS, the ability of vocational school principals in choosing alternatives solution is easier and more accurate. The DSS provides those alternative solutions which ease the vocational school principals to choose the best one. In other words, increasing the ability of problem analysis and alternatives determination will bring a positive effect on the quality of decisionmaking process made by the vocational school principals. However, the strategy in developing the information and communication systems through the internet and intranet networks in 
vocational schools needs to be applied because it is very appropriate to anticipate trends in the development of science and technology and globalization. Thus, it will be fascinating to conduct a future research on an Android-based principal's decision support system.

\section{ACKNOWLEDGMENT}

The researcher delivered special thanks to the Research Center and Community Services, Universitas Sarjanawiyata Tamansiswa, Indonesia for its internal research grant and all vocational school principals involved in this research.

\section{REFERENCES}

Abduh, H. (2015). Pengambilan keputusan di lembaga pendidikan. [Decision making in educational institutions]. HIKMAH: Jurnal Pendidikan Islam, 4(1), 26-50. https://doi.org/2085-8663.082/2114.

Abu-Samaha, A. M., \& Shishakly, R. (2008). Assessment of school information system utilization in the uae primary schools. Issues in Informing Science and Information Technology, 5, 525-542. https://doi.org/10.28945/3260.

Aldarbesti, H., \& Saxena, J. P. (2014). Management information system for education. IOSR Journal of Research \& Method in Education (IOSR-JRME), 4(1), 36-44. https://doi.org/10.9790/738804143644.

Anwar, H. (2014). Proses pengambilan keputusan untuk mengembangkan mutu madrasah. [Decision-making process to improve the quality of madrasah]. Nadwa: Jurnal Pendidikan Islam, 8(1), 37-56. https:// doi.org/10.21580/nw.2014.8.1.569.

Aryawan, I. W. (2019). Strategi kepemimpinan kepala sekolah di era revolusi industri 4.0 berlandaskan pada konsep panca upaya sandhi. [Principal leadership strategies in the age of the industrial revolution 4.0 based on the concept of panca upaya sandhi]. Jurnal Ilmiah Ilmu Sosial, 5(2), 132-141. http://dx.doi.org/10.23887/jiis. v5i2.22519.
Astuti, W. S. (2018). Hubungan kepemimpinan kepala sekolah dengan kinerja guru di SMK swasta bisnis manajemen Kecamatan Padang Barat Kota Padang. [The relationship between principal leadership and teacher performance in private business management vocational schools, West Padang District, Padang City]. Jurnal Bahana Manajemen Pendidikan, 7(2), 16-23. https://doi. org/10.24036/bmp.v7i2.5989.

Ayub, U. M., Wahyudi, \& Syukri, M. (2014). Profil kepemimpinan kepala sekolah dalam pengambilan keputusan pada pelaksanaan manajemen berbasis sekolah. [The profile of the principal's leadership in making decisions on the implementation of schoolbased management]. Jurnal Pendidikan dan Pembelajaran Khatulistiwa, 3(7), 1-16. https://jurnal.untan.ac.id/index.php/ jpdpb/article/view/6395.

Baglieri, D., Metallo, C., Rossignoli, C., \& Iacono, M. P. (Eds.). (2014). Information systems, management, organization and control: Smart practices and effects. New York, NY: Springer International Publishing. https://doi.org/10.1007/9783-319-07905-9.

Benwari, N. N., \& Dambo, B. I. (2014). Improving secondary schools management through transformational leadership approach and management information systems. Journal of Educational and Social Research, 4(6), 401-406. https://doi. org/10.5901/jesr.2014.v4n6p401.

Bigner, S. Z. (2017). Teacher and principal experiences with data-driven decision making, school improvement plan quality, and academic growth. (Dissertation, The University Of Houston-Clear Lake). https://uhcl-ir.tdl.org/handle/10657.1/728.

Bryson, J. M. (2004). Strategic planning for public and nonprofit organization: a guide to strengthening and sustaining organizational achievement ( $3^{\text {rd }}$ ed). San Francisco, CA: Jossey-Bass Publishing Co.

Chiu, P. S., \& Huang, Y. M. (2016). The 
development of a decision support system for mobile learning: a case study in Taiwan. Innovations in Education and Teaching International, 53(5), 532-544. https://doi.org/10.1080/14703297.2015.1 020328.

Doherr, H., Christalle, E., Kriston, L., Härter, M., \& Scholl, I. (2017). Use of the 9-item shared decision making questionnaire (SDM-Q-9 and SDM-Q-Doc) in intervention studies-A systematic review. PLoS ONE, 12(3), 1-16. https:// doi.org/10.1371/journal.pone.0173904.

Engkoswara, E., \& Komariah, A. (2010). Administrasi pendidikan. [Education administration]. Bandung: Alfabeta.

Fakeeh, K. A (2015). Decision Support Systems (DSS) in higher education system. International Journal of Applied Information Systems, 9(2), 32-40. https://www.ijais.org/archives/volume9/ number2/765-1366.

Gehlawat, M. (2014, April-Juni). School management information system an effective tool for augumenting the school practices. New Frontiers in Education, 57-64.

Ghaffarzadeh, Ş. A. M. (2015). Review article decision making based on management information system. Journal of Management Research and Analysis, 2(1), 98-107. http://oaji.net/ articles/2015/1875-1428995605.pdf.

Hariri, H., Monypenny, R., \& Prideaux, M. (2014). Leadership styles and decision-making styles in an indonesian school context. School Leadership \& Management, 34(3), 284-298. https://doi. org/10.1080/13632434.2013.849678.

Hermann, M., Pentek, T., \& Otto, B. (2016, 5-8 January). Design principles for industrie 4.0 scenarios. Paper presented at the 49th Hawaiian International Conference on Systems Science, Koloa, HI, USA. https:// doi.org/10.1109/HICSS.2016.488.

Hoy, W. K. \& Miskel, C. G. (2013). Educational administration: Theory, research, and practice $\left(9^{\text {th }} \mathrm{ed}\right)$. New York, NY: McGrawHill Education.

James, E. A., Milenkiewicz, M. T., \& Bucknam, A. (2008). Participatory action research for educational leadership: using data-driven decision making to improve schools. Thousand Oaks, CA: Sage Publications, Inc. https://doi. org/10.4135/9781483329369.

Kadir, A. (2017). Pengaruh otoritas pengambilan keputusan terhadap efektivitas pengelolaan sekolah di Kota Mataram. [The influence of decision making authority on the effectiveness of school management in Mataram City]. Jurnal Pendidikan Ekonomi dan Bisnis, 4(2), 107-116. $\quad$ https://doi.org/10.21009/ JPEB.004.2.2.

Kasprzhak, A. G. \& Bysik, N. V. (2015). Decision-making styles of Russian school principals. Russian Education \& Society, 57(7), 590-613. https://doi.org/10.1080/1 $\underline{0609393.2015 .1096148 .}$.

Keshtegar, A., \& Vakili, N. (2018). Comparison of Management Information System (MIS) and Decision Support System (DSS) and its role in the decision-making process of managers of Economic Affairs and Finance of Zahedan. International Review of Management and Marketing, 8(1), 93-97. https://www.econjournals. com/index.php/irmm/article/view/6049.

Lake, P., \& Drake, R. (2014). Information systems management in the big data era. Switzerland: Springer International Publishing.

Lestari, V. S. (2011). Bahan Ajar Dasardasar manajemen. [Teaching Materials in Management basics]. Makassar, Indonesia: Universitas Hasanuddin.

Lizarragaa, M. L. S. A., Baquedanoa, M. T. S. A., Olivera, M. S., \& Closas, A. (2009). Development and validation of a decision-making questionnaire. British Journal of Guidance \& Counselling, 37(3), 357-373. https://doi. 
org/10.1080/03069880902956959.

Luena, A. M. (2012). Strengthening the education management information system (EMIS) in Tanzania: government actors' perceptions about enhancing local capacity for information-based policy reforms. Master's Capstone Projects, 21, 1-57. https://scholarworks.umass.edu/ cie capstones $/ 21$.

Luo, M. (2008). Structural equation modeling for high school principals' datadriven decision making: An analysis of information use environments. Educational Administration Quarterly, 44(5), 603-634. https://doi. org/10.1177/0013161X08321506.

Montana, P. J., \& Charnov, B. H. (2008). Management $\left(4^{\text {th }}\right.$ ed). New York, NY: Barron's Educational Series, Inc.

National Forum on Education Statistics. (2006). Forum guide to decision support systems: A resource for educators (NFES 2006807). Washington, DC: National Center for Education Statistics.

Nurhidayati, R. (2015). Pengaruh budaya organisasi dan konsep diri terhadap pengambilan keputusan kepala sekolah dasar negeri di Kecamatan Jagakarsa. [The influence of organizational culture and self-concept on the decision making of public elementary school principals in Jagakarsa District]. Jurnal Manajemen Pendidikan, 6(2), 1169-1177. https://doi. org/10.21009/jmp.06208.

Omotayo, F. O., \& Chigbundu, M. C. (2017). Use of information and communication technologies for administration and management of schools in Nigeria. Journal of Systems and Information Technology, 19(3/4), 183-201. https://doi. org/10.1108/JSIT-06-2017-0045.

Permendikbud RI 2018 No. 06/D.D5/KK/2018. Spektrum keahlian sekolah menengah kejuruan (SMK)/madrasah aliyah kejuruan (MAK). [The spectrum of expertise of vocational high schools $(\mathrm{SMK}) /$ vocational madrasah aliyah
(MAK)].

Pornpandejwittaya, P. (2012). Effectiveness of AIS: Effect on performance of Thai-Listed firms in Thailand. International Journal of Business Research, 12(3), 84-94.

Putra, V. M. (2014). Persepsi guru terhadap pengambilan keputusan kepala sekolah di SMK negeri kelompok bisnis manajemen Kota Padang. [Teachers' perceptions of the principal's decision-making in public SMK in the Padang City management business group]. Jurnal Bahana Manajemen Pendidikan, 2(1), 755-763. http://ejournal.unp.ac.id/index.php/ bahana/article/view/3822.

Rochaety E., Rahayuningsih, P., \& Yanti, P. G. (2007). Sistem informasi manajemen pendidikan. [Education management information system]. Jakarta: Bumi Aksara.

Robbins, S. P. (2003). Organizational behavior. New Jersey, NJ: Prentice Hall.

Sholihin, M., \& Ratmono, D. (2014). Analisis SEM-PLS dengan WarpPLS 3.0 untuk hubungan nonlinier dalam penelitian sosial dan bisnis. [SEM-PLS analysis with WarpPLS 3.0 for nonlinear relationships in social and business research].Yogyakarta: Andi.

Silich, V.A, Savelev, A.O., \& Isaev, A.N. (2016). Methodical approach to developing a decision support system for well interventions planning. IOP Conference Series: Materials Science and Engineering, 127, 1-7. https://doi. org/10.1088/1757-899X/127/1/012016.

Singh, R., Bhardwaj, A., \& Sharma, R. (2013). Comparative study of management information system and decision support system. International Journal of Computers and Distributed Systems, 2(2), 5-8. http://journaldatabase.info/articles/ comparative study_management information.html.

Skalski, A. K \& Romero, M. (2011, January). Data-based decision making. Principal 
Leadership, 11(5), 12-16.

Slater, L. (2005). Leadership for collaboration: An affective process. International Journal of Leadership in Education, 8(4), 321-333. https://doi. org/10.1080/13603120500088745.

Syafrizal, M. (2010). Sistem pendukung keputusan (Decision support system). Jurnal DASI, 11(3), 77-90. https://ojs. amikom.ac.id/index.php/dasi/article/ view/38/24.

Tatnall, A. (2011). Information systems research, technological innovation and actornetwork theory. Melbourne: Heidelberg Press.

Telem, M. \& Pinto, S. (2006). Information technology's impact on school-parents and parents-student interrelations: A case study. Computers \& Education, 47(3), 260-279. https://doi.org/10.1016/j. compedu.2004.10.008

Thorn, C. A. (2002). Data use in the classroom: The challenges of implementing databased decision-making at the school level (Working Paper No. 2002-2). New York, NY: Wisconsin Center for Education Research.

Triwiyanto, T. (2015). Pelaksanaan monitoring, evaluasi, dan pelaporan untuk penilaian kinerja manajerial kepala sekolah. [The implementation of the monitoring, evaluation, and reporting for assessing the school principals' managerial performance]. Cakrawala Pendidikan, 34(1), 67-77. https://doi.org/10.21831/ cp.v1i1.4177.
Usman, H. (2015). Model kepemimpinan instruksional kepala sekolah. [The school principals' instructional leadership model]. Cakrawala Pendidikan, 34(3), 322-333. https://doi.org/10.21831/ cp.v3i3.7338.

Wiguna, W. (2017). Kinerja manajerial, pemanfaatan sistem informasi manajemen sekolah dan efektivitas implementasi rencana stratejik. [Managerial performance, utilization of school management information systems and effectiveness of implementing strategic plans]. Jurnal Administrasi Pendidikan, 24(1), 130-140. https://ejournal.upi.edu/ index.php/JAPSPs/article/view/6501/0.

Wiyardi, W. (2016). Kepemimpinan kepala sekolah, sistem informasi manajemen, dan formulasi rencana strategis. [Principal leadership, management information systems, and strategic plan formulation]. Jurnal Administrasi Pendidikan, 23(2), 14-25. https://ejournal.upi.edu/index. php/JAPSPs/article/view/5630.

Yanti, H. (2013). Persepsi guru terhadap pengambilan keputusan oleh kepala sekolah di SMP Negeri Kecamatan Rambatan Kabupaten Tanah Datar. [Teachers' perceptions of decision making by school principals at SMP Negeri Rambat Subdistrict, Tanah Datar Regency]. Jurnal Bahana Manajemen Pendidikan, 1(1), 84-92. http://ejournal. unp.ac.id/index.php/bahana/article/ view/2684.

Yukl, G. (2003). Leadership in organizations. Upper Saddle River, NJ: Prentice Hall. 